\title{
Lactobacillus delbrueckii subsp. sunkii subsp. nov., isolated from sunki, a traditional Japanese pickle
}

Correspondence

Koichi Watanabe

koichi-watanabe@yakult.co.jp

\author{
Yuko Kudo, Kaihei Oki and Koichi Watanabe \\ Yakult Central Institute for Microbiological Research, 1796 Yaho, Kunitachi, Tokyo 186-8650, \\ Japan
}

\begin{abstract}
Although four strains of bacteria isolated from sunki, a traditional Japanese, non-salted pickle, were initially identified as Lactobacillus delbrueckii, the molecular and phenotypic characteristics of the strains did not match those of any of the four recognized subspecies of $L$. delbrueckii. Together, the results of phenotypic characterization, DNA-DNA hybridizations (in which the relatedness values between the novel strains and type strains of the recognized subspecies of $L$. delbrueckii were all $>88.7 \%$ ) and 16S rRNA gene sequence, amplified fragment length polymorphism (AFLP) and whole-cell MALDI-TOF/MS spectral pattern analyses indicated that the four novel strains represented a single, novel subspecies, for which the name Lactobacillus delbrueckii subsp. sunkii subsp. nov. is proposed. The type strain is YIT $11221^{\top}\left(=\mathrm{JCM} 17838^{\top}\right.$ $=$ DSM 24966 ${ }^{\top}$ ).
\end{abstract}

Sunki is a traditional, Japanese, non-salted pickle that is produced by the fermentation of the leaves of red turnips ('otaki-kabu'). The turnips used for the pickle are cultivated in Kiso county, in the Nagano prefecture of Japan. To prepare the pickle, the turnip leaves are harvested in late autumn, parboiled for $10-15 \mathrm{~s}$ and then allowed to ferment at a low temperature $\left(10-15{ }^{\circ} \mathrm{C}\right)$ for $1-2$ weeks. The parboiled leaves are sometimes inoculated with dried, well-fermented sunki, prepared the previous year, as a starter. During a study on the biodiversity of the lactic acid bacteria (LAB) associated with the fermentation of sunki (Watanabe et al., 2009), four novel species - Lactobacillus kisonensis, Lactobacillus otakiensis, Lactobacillus rapi and Lactobacillus sunkii - were identified as the predominant species in 33 samples of pickling solution used in sunki production in Kiso county, while Lactobacillus delbrueckii was identified as the subdominant LAB component. In Koso county, which is also in Nagano prefecture, Endo et al. (2008) identified L. delbrueckii, Lactobacillus fermentum and Lactobacillus plantarum as the predominant species in the fermentation of sunki samples collected from four families.

L. delbrueckii plays an important part in the production of many fermented foods of both plant and animal origin. It

\footnotetext{
Abbreviations: AFLP, amplified fragment length polymorphism; LAB, lactic acid bacteria; MALDI-TOF/MS, matrix-assisted laser desorption/ ionization time-of-flight mass spectrometry.

The GenBank/EMBL/DDBJ accession numbers for the 16S rRNA gene sequences of strains YIT 11211 ${ }^{\top}$, YIT 11220, YIT 11446 and YIT 11673 are AB641833, AB641832, AB641834 and AB641835, respectively.

Two supplementary tables and a supplementary figure are available with the online version of this paper.
}

has been isolated from the fermented brines used in the production of stinky tofu in Taiwan (Chao et al., 2008a). At the time of writing, four subspecies of this species are recognized. Although Lactobacillus delbrueckii subsp. bulgaricus has been isolated mainly from fermented milk, it has recently also been detected in Bulgarian plants (Michaylova et al., 2007). Lactobacillus delbrueckii subsp. delbrueckii, which lacks a lactose operon, has been found in fermented plant materials (Germond et al., 2003), while Lactobacillus delbrueckii subsp. indicus has been isolated from fermented dairy products in India (Dellaglio et al., 2005). Most isolates of the other recognized subspecies of L. delbrueckii, Lactobacillus delbrueckii subsp. lactis, have come from cheeses (Weiss et al., 1983).

Although the reliable identification of $L$. delbrueckii at the subspecies level may be important in the production of several fermented foods, the sugar fermentation tests and other phenotypic characterizations that are frequently employed (Weiss et al., 1983) often give ambiguous results. Since 1999, the potential use of molecular methods to distinguish the subspecies of $L$. delbrueckii has therefore been explored. For example, randomly amplified polymorphic DNA (RAPD) PCR and proline iminopeptidase (pepIP) gene sequence analysis have been used to distinguish $L$. delbrueckii subsp. bulgaricus from other subspecies of L. delbrueckii (Torriani et al., 1999). The analysis of cellwall proteins by SDS-PAGE was used to distinguish $L$. delbrueckii subsp. delbrueckii from $L$. delbrueckii subsp. bulgaricus (Gatti et al., 2001), while restriction fragment length polymorphism (RFLP) analysis of bacterial proteincoding genes was used both to characterize L. delbrueckii subsp. lactis and L. delbrueckii subsp. bulgaricus and to distinguish between these two subspecies (Giraffa et al., 
2003). Germond et al. (2003) investigated 16S rRNA gene sequence mutations, expression of $\beta$-galactosidase and cellwall-anchored protease, galactose metabolism and the distribution of insertion sequences (IS elements), as well as characterizing the lactose operon locus and lacR gene sequences, in L. delbrueckii subsp. lactis, L. delbrueckii subsp. bulgaricus and $L$. delbrueckii subsp. delbrueckii. Unfortunately, none of these analyses was found useful for distinguishing L. delbrueckii subsp. delbrueckii from the other subspecies of $L$. delbrueckii that were then recognized, although another type of molecular characterization, amplified-fragment length polymorphism (AFLP) analysis, did allow the identification of L. delbrueckii subsp. indicus as a fourth subspecies (Dellaglio et al., 2005).

Tanigawa \& Watanabe (2011) recently investigated 41 strains of $L$. delbrueckii, by AFLP analysis, the multilocus sequence typing (MLST) of seven housekeeping genes (fusA, gyrB, hsp60, ileS, pyrG, recA and recG) and sugar fermentation tests. The results indicated that some reclassification of the subspecies of $L$. delbrueckii might be necessary, since the strains of L. delbrueckii subsp. bulgaricus formed a cluster that was surprisingly distinct from the cluster formed by strains of L. delbrueckii subsp. indicus. Furthermore, the type strain of $L$. delbrueckii subsp. delbrueckii was clearly separate from the other strains currently classified as members of this subspecies, which appeared more closely related to the investigated strains of $L$. delbrueckii subsp. lactis. Tanigawa \& Watanabe (2011) also suggested that the four strains derived from sunki that they investigated represented a novel subspecies of $L$. delbrueckii.

In 2004, four strains of bacteria, designated YIT 11220, YIT $11221^{\mathrm{T}}$, YIT 11466 and YIT 11673 , were isolated from samples of sunki and initially identified as $L$. delbrueckii. Since the molecular and phenotypic characteristics of these strains did not match those of any of the four recognized subspecies of $L$. delbrueckii, the taxonomic positions of the strains were investigated by following a polyphasic approach. For reference, L. delbrueckii subsp. bulgaricus YIT $0181^{\mathrm{T}}$ $\left(=\right.$ ATCC $\left.11842^{\mathrm{T}}\right)$, L. delbrueckii subsp. delbrueckii YIT $0080^{\mathrm{T}}$ $\left(=\right.$ ATCC $\left.9649^{\mathrm{T}}\right)$, L. delbrueckii subsp. indicus YIT $11751^{\mathrm{T}}$ $\left(=\mathrm{DSM} 15996^{\mathrm{T}}\right)$ and $L$. delbrueckii subsp. lactis YIT $0086^{\mathrm{T}}$ $\left(=\right.$ ATCC $\left.12315^{\mathrm{T}}\right)$ and 19 other strains previously assigned to a subspecies of $L$. delbrueckii were obtained from the culture collection of the Yakult Central Institute in Tokyo, Japan (Table S1, available in IJSEM Online). Prior to testing, unless indicated otherwise, the novel and reference strains were grown for 1 or 2 days, at $37^{\circ} \mathrm{C}$ and $\mathrm{pH} 6.8$, in MRS broth (Difco; de Man et al., 1960).

The genomic DNA used in the analysis of 16S rRNA gene sequences and AFLP typing was prepared according to the method of Watanabe et al. (2008). The methods used for the amplification and subsequent sequencing of $16 \mathrm{~S}$ rRNA genes were those described by Chao et al. (2008b). The PCR mixture $(25 \mu \mathrm{l})$ contained $10 \mathrm{mM}$ Tris/ $\mathrm{HCl}(\mathrm{pH} 8.3)$, $50 \mathrm{mM} \mathrm{KCl}, 200 \mu \mathrm{M}$ of each deoxyribonucleotide triphosphate, $1 \mathrm{mM} \mathrm{MgCl}_{2}, 1 \mu \mathrm{g}$ BSA, $0.5 \mathrm{U}$ Taq DNA polymerase (Takara Bio), $0.1 \mu \mathrm{M}$ of each primer and $10 \mathrm{ng}$ template DNA. The thermocycler was set to give an initial denaturation step of $2 \mathrm{~min}$ at $94{ }^{\circ} \mathrm{C}$, followed by 30 cycles, each of $20 \mathrm{~s}$ at $94{ }^{\circ} \mathrm{C}, 30 \mathrm{~s}$ at $55^{\circ} \mathrm{C}$ and $20 \mathrm{~s}$ at $72{ }^{\circ} \mathrm{C}$, and then a final extension of $3 \mathrm{~min}$ at $72{ }^{\circ} \mathrm{C}$. The amplicons were purified, using a Montage PCR filter unit (Millipore) according to the manufacturer's instructions, before being sequenced by using version 3.1 of the ABI PRISM BigDye Terminator cycle sequencing kit (Applied Biosystems) and an ABI PRISM 3130xl genetic analyser (Applied Biosystems). The sequences were assembled using version 2.1 of the Autoassembler package (Applied Biosystems) and version 15.0 of the GENETYX-MAC package (Software Development). The closest known relatives of the novel strains were identified using FASTA (Pearson \& Lipman, 1988), before the relevant sequences of the closely related species were retrieved from the GenBank/EMBL/DDBJ databases. Multiple alignment of the sequences was carried out with version 2.0.12 of the program CLUSTAL_X (Thompson et al., 1997). The almost-complete 16S rRNA gene sequences of the novel strains and strains of related species were used in the construction of a neighbourjoining phylogenetic tree (Saitou \& Nei, 1987). The topology of the tree was evaluated by bootstrap analysis with 1000 replicates (Felsenstein, 1985). The MEGA4 package (Tamura et al., 2007) was used to construct minimumevolution (Rzhetsky \& Nei, 1992) and maximum-parsimony (Fitch, 1971) trees, using the same sequences and the Kimura two-parameter model (Kimura, 1980). The novel strain YIT $11221^{\mathrm{T}}$ appeared to be closely related to the type strains of all four recognized subspecies of $L$. delbrueckii (i.e. L. delbrueckii subsp. bulgaricus YIT $0181^{\mathrm{T}}$, L. delbrueckii subsp. delbrueckii YIT $0080^{\mathrm{T}}$, L. delbrueckii subsp. indicus YIT $11751^{\mathrm{T}}$ and L. delbrueckii subsp. lactis YIT $0086^{\mathrm{T}}$ ), with $16 \mathrm{~S}$ rRNA gene sequence similarities of at least $98.8 \%$. In the neighbour-joining phylogenetic tree based on $16 \mathrm{~S}$ rRNA gene sequences, the four novel strains were placed in a cluster formed of members of the species L. delbrueckii (Fig. S1). Similar topologies were seen in the corresponding minimum-evolution and maximum-parsimony trees (data not shown).

AFLP analysis was performed by following the method of Tanigawa \& Watanabe (2011) and using EcoRI and MseI ligation/amplification modules (Applied Biosystems). Total DNA was digested with EcoRI and MseI restriction enzymes (Takara Bio) before the DNA fragments were ligated to double-stranded restriction-site-specific EcoRI and MseI adaptors. The primers EcoRI-A (5'GACTGCATACCACCAATTCA- $\left.3^{\prime}\right)$ and MseI-CA (5'AATGAGTCCTGAGTAGCA- $\overline{3^{\prime}}$ ) were used for the preselective and selective PCR [the selective base(s) at the $3^{\prime}$-end of each primer are underlined]. The amplicons were analysed on an ABI PRISM 3130xl genetic analyser in standard fragment-analysis mode, using GENESCAN-500 LIZ (Applied Biosystems) as the size standard. After electrophoresis, the AFLP patterns were recorded and analysed using version 4.0 of the GeneMapper package 


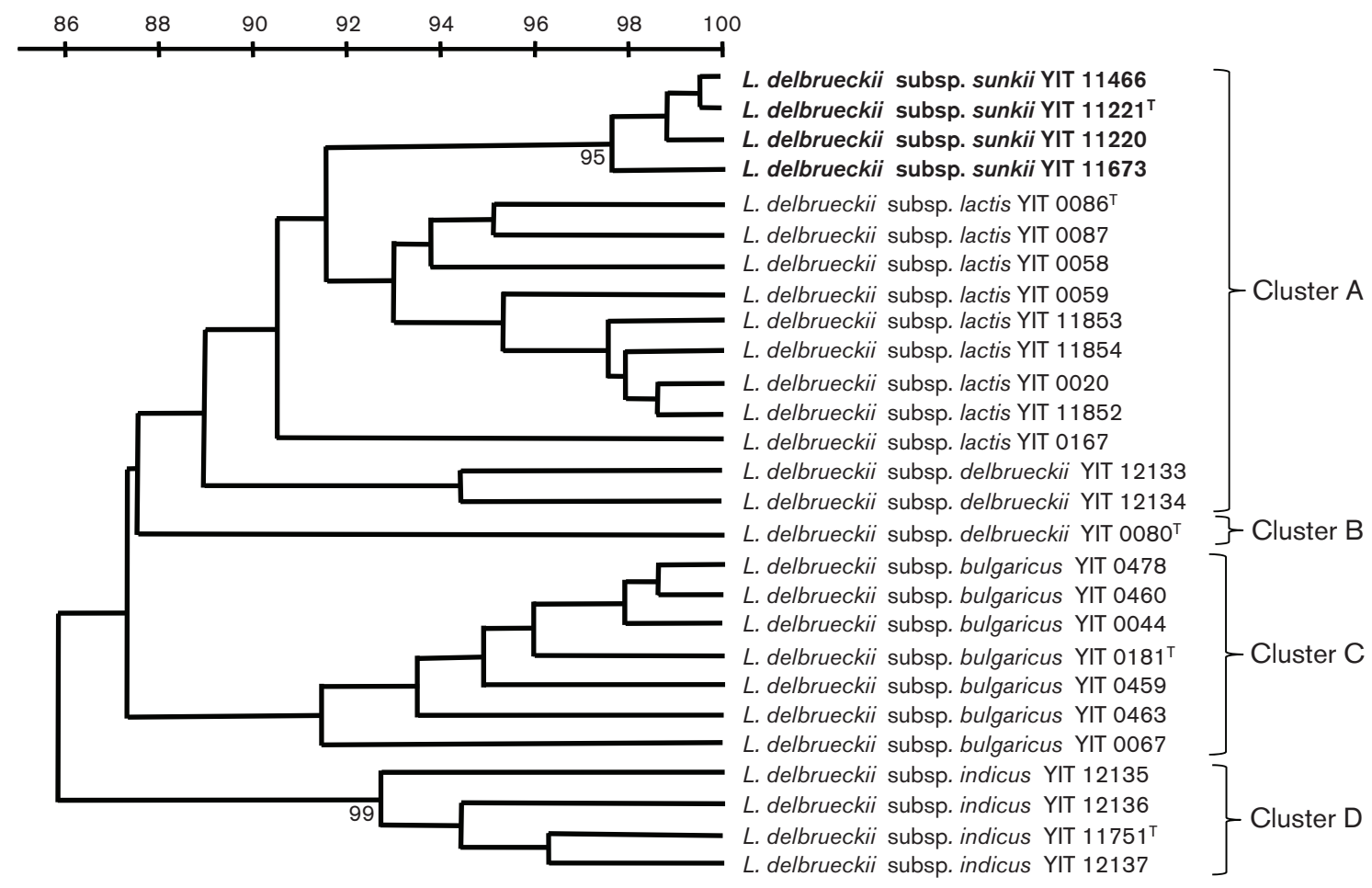

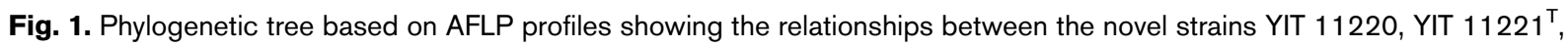
YIT 11446 and YIT 11673 and closely related strains belonging to the species Lactobacillus delbrueckii. Bootstrap values $\geqslant 95 \%$ (based on 100 replications) are shown at branching points. Bar, percentage band similarity.

(Applied Biosystems). A threshold fluorescence value of 100 arbitrary units was used to eliminate background fluorescence, and only DNA fragments of 51-500 bp were analysed. Fragments from different strains that had the same length were assumed to be identical and were classified as the same alleles. Bands of different sizes were treated as independent loci, each with two alleles (present or absent). The data, which were exported in binary format (with 1 and 0 indicating the presence and absence of a particular band, respectively) were analysed in the package MEGA4. For this analysis, an unweighted pair-group method with arithmetic means (UPGMA; Sneath \& Sokal, 1973) and Dice coefficient, with a bootstrap analysis involving 100 repetitions, were used. The 27 strains included in the analysis were separated into four major clusters (Fig. 1). Cluster A consisted of two strains of $L$. delbrueckii subsp. delbrueckii, nine of L. delbrueckii subsp. lactis and the four novel strains. Cluster B comprised only a single strain (the type strain of $L$. delbrueckii subsp. delbrueckii), cluster C consisted of seven strains of $L$. delbrueckii subsp. bulgaricus and cluster D consisted of four strains of L. delbrueckii subsp. indicus. Within cluster A, the four novel strains, whose band similarities were $>97 \%$, formed a distinct subcluster (Fig. 1).

Cell protein for analysis by matrix-assisted laser desorption/ionization time-of-flight mass spectrometry (MALDITOF/MS) was extracted by the ethanol/formic acid method. Briefly, $4 \mathrm{ml}$ culture (incubated overnight) was centrifuged at $14000 \mathrm{~g}$ for $5 \mathrm{~min}$. The resultant cell pellet was washed twice in double-distilled water before the cells were resuspended in $500 \mu \mathrm{l}$ of $70 \%(\mathrm{v} / \mathrm{v})$ ethanol and then centrifuged down at $10000 \mathrm{~g}$ for $2 \mathrm{~min}$. The pellet produced was mixed with $10 \mu \mathrm{l}$ of $70 \%(\mathrm{v} / \mathrm{v})$ formic acid, by vortexing, and then gently mixed with $10 \mu$ lacetonitrile. The resulting mixture was centrifuged, again at $10000 \mathrm{~g}$ for $2 \mathrm{~min}$, before $0.5 \mu \mathrm{l}$ supernatant solution was applied to a FlexiMass-DS disposable MALDI target (Shimadzu), airdried and then overlaid with $1 \mu \mathrm{l}$ matrix solution, which comprised $\alpha$-cyano-4-hydroxycinnamic acid (Shimadzu) at a concentration of $20 \mathrm{mg} \mathrm{ml}^{-1}$ (3\% trifluoroacetic acid/ $33 \%$ acetonitrile/33\% ethanol). MALDI mass spectra in the range of 2000-20000 molecular masses $(\mathrm{m} / \mathrm{z})$ were recorded, in positive linear mode, by averaging 500 individual laser shots made in an Axima Performance MALDI-TOF/TOF spectrometer (Shimadzu) equipped with a pulsed $\mathrm{N}_{2}$ laser $(\lambda=337.1 \mathrm{~nm}$; pulse width $=3 \mathrm{~ns}$; frequency $=50 \mathrm{~Hz}$ ). The spectra were calibrated externally by using Escherichia coli DH5 $\alpha$ electro cells (Takara Bio) as the reference standards. MALDI-TOF/MS peaks from different strains that showed the same $\mathrm{m} / \mathrm{z}$ value were assumed to be identical and were classified as the same alleles. Peaks of different $\mathrm{m} / \mathrm{z}$ were treated as independent loci with two alleles (present or absent). Data were exported in binary format and analysed like those from 


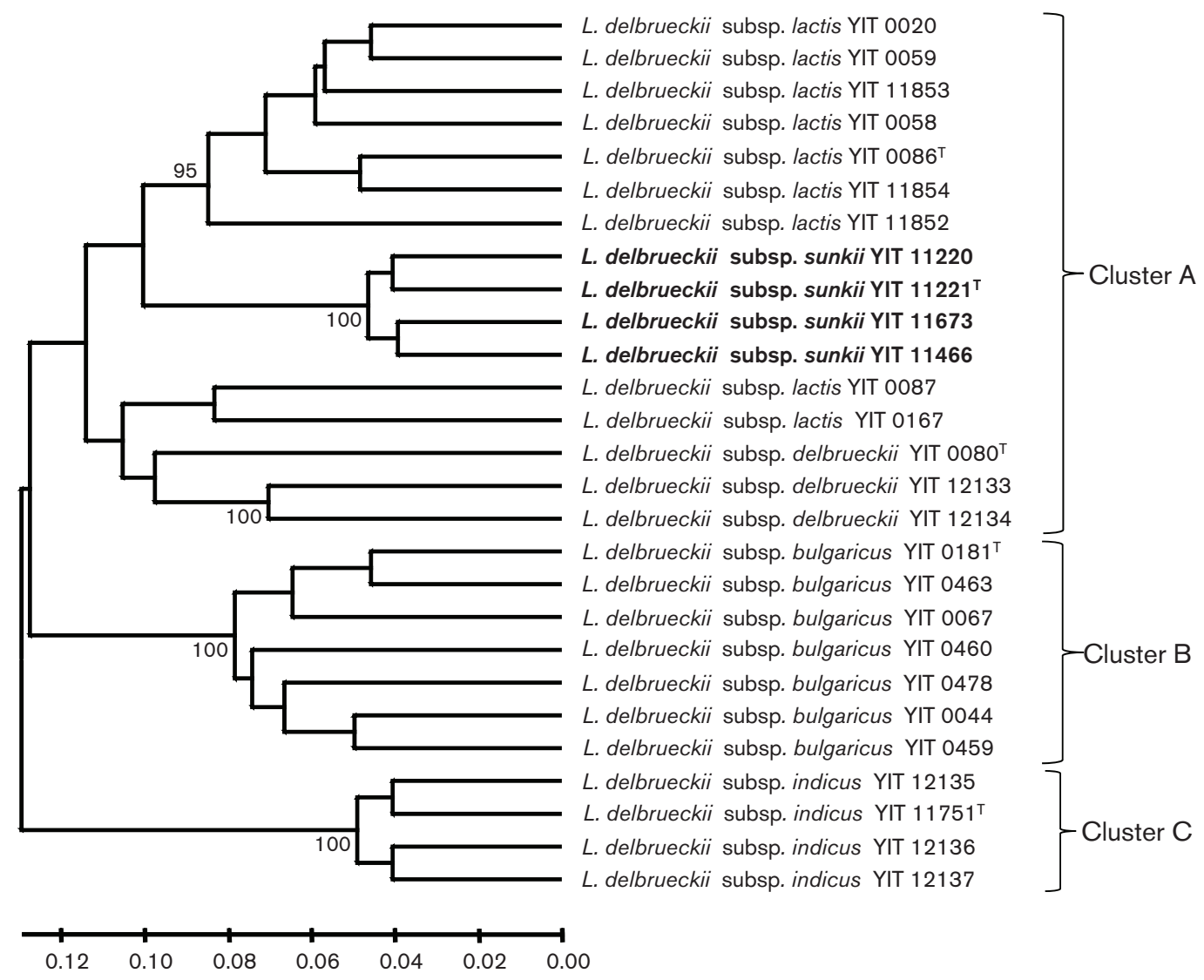

Fig. 2. Phylogenetic tree based on MALDI-TOF/MS patterns showing the relationships between the novel strains YIT 11220 , YIT $11221^{\top}$, YIT 11446 and YIT 11673 and closely related strains belonging to the species Lactobacillus delbrueckii. Bootstrap values $\geqslant 95 \%$ (based on 100 replications) are shown at branching points. Bar, proportion of peaks that are different.

the AFLP analysis. The 27 L. delbrueckii strains included in the MALDI-TOF/MS analysis were separated into three major clusters (Fig. 2). Cluster A consisted of three strains of $L$. delbrueckii subsp. delbrueckii, nine of $L$. delbrueckii subsp. lactis and the four novel strains. Cluster B consisted of seven strains of $L$. delbrueckii subsp. bulgaricus while cluster C consisted of four strains of $L$. delbrueckii subsp. indicus. In the tree based on MALDI-TOF/MS patterns (Fig. 2), as in the tree based on AFLP patterns, the four novel strains formed a tight, separate subcluster in cluster A.

The genomic DNA used to determine the DNA G+C contents of the novel and reference strains and to investigate DNA-DNA relatedness values among the same strains was extracted according to the method of Marmur (1961). To assess its G $+C$ content, DNA was enzymically degraded into nucleosides (Mesbah et al., 1989) and then separated by HPLC. The genomic DNA G $+\mathrm{C}$ contents of the four novel strains $(50.9-51.7 \mathrm{~mol} \%)$ were very similar to the corresponding values for the type strains of the four recognized subspecies of $L$. delbrueckii (50.5-54.3 mol\%).
DNA-DNA hybridizations were performed in microdilution wells; photobiotin was used for the DNA labelling (Ezaki et al., 1989). Reciprocal hybridization experiments were carried out at $45{ }^{\circ} \mathrm{C}$ for $2 \mathrm{~h}$ in the presence of $50 \%$ $(\mathrm{v} / \mathrm{v})$ formamide, using biotinylated DNA and unlabelled, single-strand DNA that had been bonded, non-covalently, to microplate wells. For each hybridization, the highest and lowest values from eight replicate wells were excluded before the means of the six remaining values were calculated and recorded as a relatedness value. The DNADNA relatedness values among the four novel strains were high (at least 94.8\%), whereas those between strain YIT $11221^{\mathrm{T}}$ and L. delbrueckii subsp. bulgaricus YIT $0181^{\mathrm{T}}(91.6 \%)$, L. delbrueckii subsp. delbrueckii YIT $0080^{\mathrm{T}}$ (88.7\%), L. delbrueckii subsp. indicus YIT $11751^{\mathrm{T}}$ (90.1\%) and L. delbrueckii subsp. lactis YIT $0086^{\mathrm{T}}(89.0 \%)$ were slightly lower. These values indicate that the four novel strains belong to a single taxon within the species $L$. delbrueckii (Table S2).

Morphological, cultural and biochemical tests were performed, according to standard techniques, at $37^{\circ} \mathrm{C}$ unless 
Table 1. Major characteristics that can be used to distinguish the novel strains YIT 11220 , YIT $11221^{\top}$, YIT 11446 and YIT $_{11673}$ from the type strains of the four established subspecies of Lactobacillus delbrueckii

Strains: 1, YIT 11220; 2, YIT 11221 ${ }^{\mathrm{T}}$; 3, YIT 11466; 4, YIT 11673; 5, L. delbrueckii subsp. bulgaricus YIT 0181 ${ }^{\mathrm{T}}$; 6, L. delbrueckii subsp. delbrueckii YIT $0080^{\mathrm{T}} ; 7$, L. delbrueckii subsp. indicus YIT $11751^{\mathrm{T}} ; 8$, L. delbrueckii subsp. lactis YIT $0086^{\mathrm{T}}$. All data are from this study. All eight strains produced acid from D-glucose, D-fructose and D-mannose. None of the strains produced acid from glycerol, erythritol, D- or L-arabinose, D-ribose, D- or Lxylose, D-adonitol, methyl $\beta$-D-xylopyranoside, L-sorbose, L-rhamnose, dulcitol, inositol, D-sorbitol, methyl $\alpha$-D-mannopyranoside, inulin, melezitose, starch, glycogen, xylitol, turanose, D-lyxose, D-tagatose, D- or L-fucose, D- or L-arabitol, gluconate, 2-ketogluconate or 5-ketogluconate. + , Positive; -, negative; $\mathrm{w}$, weakly positive.

\begin{tabular}{|c|c|c|c|c|c|c|c|c|}
\hline Characteristics & 1 & 2 & 3 & 4 & 5 & 6 & 7 & 8 \\
\hline $15{ }^{\circ} \mathrm{C}$ & $\mathrm{W}$ & $\mathrm{W}$ & $\mathrm{w}$ & $\mathrm{w}$ & - & - & - & - \\
\hline $4 \%(\mathrm{w} / \mathrm{v}) \mathrm{NaCl}$ & $\mathrm{w}$ & $\mathrm{w}$ & $\mathrm{w}$ & $\mathrm{w}$ & $\mathrm{w}$ & $\mathrm{W}$ & - & + \\
\hline $\mathrm{NH}_{3}$ production from L-arginine & + & + & + & + & - & - & - & - \\
\hline \multicolumn{9}{|l|}{ Fermentation of: } \\
\hline$N$-Acetyl-D-glucosamine & + & + & + & + & - & + & + & + \\
\hline Amygdalin & + & + & $\mathrm{w}$ & + & - & - & + & + \\
\hline Arbutin & + & + & $\mathrm{w}$ & + & - & - & + & + \\
\hline Salicin & + & + & + & + & - & - & - & + \\
\hline Cellobiose & + & + & $\mathrm{w}$ & + & - & - & + & + \\
\hline D-Trehalose & + & + & + & + & - & - & - & + \\
\hline Raffinose & + & + & + & + & - & - & - & $\mathrm{w}$ \\
\hline Gentiobiose & $\mathrm{w}$ & $\mathrm{w}$ & $\mathrm{w}$ & $\mathrm{w}$ & - & - & - & - \\
\hline Aesculin hydrolysis & + & + & + & + & - & - & + & - \\
\hline DNA G $+C$ content $(\mathrm{mol} \%)$ & 50.9 & 51.0 & 51.7 & 51.5 & 51.6 & 54.3 & 50.5 & 51.6 \\
\hline
\end{tabular}

otherwise stated. Cell shape, cell size and Gram staining were determined by using cultures grown in MRS broth at $30{ }^{\circ} \mathrm{C}$ for $16 \mathrm{~h}$. Motility was tested in soft MRS agar that contained $0.15 \%(\mathrm{w} / \mathrm{v})$ agar. Catalase activity was also determined using cells grown on MRS agar. Gas production from glucose was measured with a Durham tube in MRS broth. Production of dextran was assessed on MRS agar in which the usual glucose had been replaced with $2 \%$ (w/v) sucrose. The methods of Barrow \& Feltham (1993) were used to determine growth at various temperatures and $\mathrm{pH}$ values and growth with various concentrations of $\mathrm{NaCl}$, and to determine if the novel strains reduced nitrate and/or produced ammonia from arginine. Carbohydrate fermentation tests were conducted by using the API 50 CHL system (bioMérieux) according to the manufacturer's instructions. The presence of diaminopimelic acid in the cell-wall peptidoglycan was investigated by the method of Kandler \& Weiss (1986). Cell-wall peptidoglycan was prepared and hydrolysed according to the method of Schleifer \& Kandler (1972) so that the amino acids could be analysed, by HPLC, in an Alliance 2695 system (Waters) equipped with a fluorescence detector (model 474; Waters) and an AccQ-Tag column $(3.9 \times 150 \mathrm{~mm}$; Waters $)$. The
AccQ-Fluor reagent (Waters), 6-aminoquinolyl- $N$-hydroxysuccinimidyl carbamate, was used for the derivatization.

Cellular fatty acid methyl esters were obtained from cells grown on MRS agar at $30{ }^{\circ} \mathrm{C}\left(\right.$ YIT $11221^{\mathrm{T}}$ ) or $37{ }^{\circ} \mathrm{C}$ (other strains) for 3 days by saponification, methylation and extraction using the method of Miller (1982) with minor modifications (Kuykendall et al., 1988). Fatty acids were then identified by following the protocol of the Sherlock Microbial Identification System (MIDI) and using the MOORE5 library. The isomers of lactic acid formed from glucose were determined by using the TC D-/L-lactic acid test kit (Boehringer Mannheim).

The four novel strains differed from the type strains of the four recognized subspecies of $L$. delbrueckii in several phenotypic characteristics. For example, all four novel strains were positive for acid production from D-mannitol, melibiose and gentiobiose, growth at $15{ }^{\circ} \mathrm{C}$ and ammonia production from L-arginine whereas all of the type strains of the recognized subspecies of $L$. delbrueckii were negative for all of these characteristics (Table 1). Based on the genotypic, proteomic and phenotypic evidence, the four novel strains represent a single novel subspecies of $L$. 
Table 2. Cellular fatty acid contents (\%) of the novel strain YIT $11221^{\top}$ and the type strains of the four established subspecies of Lactobacillus delbrueckii

Strains: 1, YIT $11221^{\mathrm{T}} ; 2$, L. delbrueckii subsp. bulgaricus YIT $0181^{\mathrm{T}} ; 3$, L. delbrueckii subsp. delbrueckii YIT $0080^{\mathrm{T}} ; 4$, L. delbrueckii subsp. indicus YIT $11751^{\mathrm{T}} ; 5$, L. delbrueckii subsp. lactis YIT $0086^{\mathrm{T}}$. All data are from this study. -, Not detected; DMA, dimethylacetal; ECL, equivalent chain-length. $\mathrm{C}_{16: 1} \omega 5 c, \mathrm{C}_{18: 1} \omega 9 c$ DMA, iso- $\mathrm{C}_{17: 0}$ and $\mathrm{C}_{18: 0} 12-\mathrm{OH}$ were not detected in any strains.

\begin{tabular}{|c|c|c|c|c|c|}
\hline Fatty acid & 1 & 2 & 3 & 4 & 5 \\
\hline \multicolumn{6}{|l|}{ Saturated } \\
\hline $\mathrm{C}_{12: 0}$ & 0.49 & 1.19 & 1.31 & 1.03 & 2.05 \\
\hline $\mathrm{C}_{14: 0}$ & 2.31 & 1.65 & 1.38 & 2.34 & 1.67 \\
\hline $\mathrm{C}_{15: 0}$ & 0.11 & - & - & - & - \\
\hline $\mathrm{C}_{16: 0}$ & 47.58 & 5.54 & 32.66 & 38.94 & 6.20 \\
\hline $\mathrm{C}_{17: 0}$ & 0.28 & 1.53 & 0.14 & 0.10 & 0.24 \\
\hline $\mathrm{C}_{18: 0}$ & - & - & 4.46 & 3.29 & 3.47 \\
\hline $\mathrm{C}_{20: 0}$ & 0.16 & - & - & - & - \\
\hline \multicolumn{6}{|l|}{ Unsaturated } \\
\hline $\mathrm{C}_{16: 1} \omega 7 c$ & 12.83 & 20.90 & 1.76 & 8.63 & 1.03 \\
\hline $\mathrm{C}_{18: 1} \omega 5 c$ & 0.65 & - & - & - & - \\
\hline $\mathrm{C}_{18: 1} \omega 6 c$ & 32.66 & - & - & - & - \\
\hline $\mathrm{C}_{18: 1} \omega 9 c$ & - & 31.60 & 47.37 & 14.17 & 44.67 \\
\hline $\mathrm{C}_{18: 1} \omega 7 c$ DMA & 1.30 & 0.25 & 0.27 & 0.23 & 0.87 \\
\hline $\mathrm{C}_{18: 2} \omega 6,9 c$ & - & - & - & - & 0.36 \\
\hline $\mathrm{C}_{20: 1} \omega 10 c$ & - & 0.14 & - & - & - \\
\hline \multicolumn{6}{|l|}{ Cyclo } \\
\hline $\mathrm{C}_{17: 0}$ cyclo & - & 0.89 & - & 1.71 & - \\
\hline $\mathrm{C}_{19: 0}$ cyclo 9,10 & - & 24.21 & - & 17.06 & 34.52 \\
\hline $\mathrm{C}_{19: 0}$ cyclo 11,12 & - & - & - & 5.00 & - \\
\hline $\mathrm{C}_{19: 0}$ cyclo $11,12 \mathrm{DMA}$ & - & - & - & 0.21 & - \\
\hline \multicolumn{6}{|l|}{ Branched-chain } \\
\hline anteiso- $\mathrm{C}_{17: 0}$ & 0.11 & 0.54 & - & - & - \\
\hline \multicolumn{6}{|l|}{ Hydroxy } \\
\hline $\mathrm{C}_{15: 0} 3-\mathrm{OH}$ & 0.31 & 0.21 & - & - & - \\
\hline \multicolumn{6}{|l|}{ Unknown } \\
\hline ECL 18.199 & - & 0.67 & 0.51 & 0.47 & 1.44 \\
\hline \multicolumn{6}{|l|}{ Summed features ${ }^{*}$} \\
\hline 10 & - & 10.41 & 9.73 & 6.32 & 2.44 \\
\hline 12 & 1.22 & 0.26 & 0.42 & 0.50 & 1.05 \\
\hline
\end{tabular}

* Summed features represent groups of two or more fatty acids that could not be separated by GLC with the MIDI system. Summed feature 10 contained $\mathrm{C}_{18: 1} \omega 7 c$ and/or an unknown with an ECL of 17.834; summed feature 12 contained an unknown with an ECL of $18.622 \mathrm{and} /$ or iso- $\mathrm{C}_{19: 0 \text {. }}$

delbrueckii, for which the name Lactobacillus delbrueckii subsp. sunkii subsp. nov. is proposed.

\section{Description of Lactobacillus delbrueckii subsp. sunkii subsp. nov.}

Lactobacillus delbrueckii subsp. sunkii (sun'ki.i. N.L. gen. n. sunkii of sunki, the name of the non-salted, traditional, Japanese pickle from which the type strain was isolated).
Cells are rod-shaped $(0.4-0.6 \times 2.0-5.0 \mu \mathrm{m})$ and occur singly, in pairs or in short chains of three or four cells. Gram-staining-positive, non-motile, non-spore-forming and facultatively anaerobic. Negative for catalase and pseudocatalase activities. After anaerobic growth for $48 \mathrm{~h}$ at $30{ }^{\circ} \mathrm{C}$, colonies on MRS agar are beige, with a smooth to rough surface, circular or slightly irregular in outline and approximately $2-4 \mathrm{~mm}$ in diameter. In MRS broth, weak growth occurs at $15{ }^{\circ} \mathrm{C}$ but no growth occurs at $45{ }^{\circ} \mathrm{C}$. Growth occurs at $\mathrm{pH} 4.0$. Weak growth occurs with $4 \%$ $(\mathrm{w} / \mathrm{v}) \mathrm{NaCl}$. Gas is not produced from glucose. The main end-product of glucose fermentation is D-lactate. Ammonia is produced from L-arginine. Nitrate is not reduced. Acid is produced from D-glucose, D-fructose, D-mannose, D-mannitol, $N$-acetyl-D-glucosamine, amygdalin, arbutin, salicin, cellobiose, maltose, melibiose, sucrose, D-trehalose, raffinose and gentiobiose but not from glycerol, erythritol, D- or L-arabinose, D-ribose, $\mathrm{D}$ - or L-xylose, $\mathrm{D}$-adonitol, methyl $\beta$ D-xylopyranoside, D-galactose, L-sorbose, L-rhamnose, dulcitol, inositol, D-sorbitol, methyl $\alpha$-D-mannopyranoside, methyl $\alpha$-D-glucopyranoside, lactose, inulin, melezitose, starch, glycogen, xylitol, turanose, D-lyxose, D- or L-fucose, D- or L-arabitol, gluconate, 2-ketogluconate or 5-ketogluconate. Acid production from D-galactose is strain-dependent. Aesculin is hydrolysed. Dextran is not produced from sucrose. Cells do not contain meso-diaminopimelic acid in their cell-wall peptidoglycan. In the presence of Lys, Glu, Ala and Asp, peptidoglycan structure is of the L-Lys-D-Asp type. The major cellular fatty acids are the saturated fatty acid $\mathrm{C}_{16: 0}$ and the unsaturated fatty acid $\mathrm{C}_{18: 1} \omega 6 c$ (Table 2). No cyclopropane is present.

The type strain, YIT $11221^{\mathrm{T}} \quad\left(=\mathrm{JCM} 17838^{\mathrm{T}}=\mathrm{DSM}\right.$ $24966^{\mathrm{T}}$ ), was isolated from sunki, a traditional, Japanese pickle, in the Nagano prefecture of Japan. The genomic DNA $G+C$ content of the type strain is $51.0 \mathrm{~mol} \%$.

\section{Acknowledgements}

We thank Keisuke Shima (Shimadzu Corporation) for his technical assistance in the proteomic characterization using MALDI-TOF/MS.

\section{References}

Barrow, G. I. \& Feltham, R. K. A. (editors) (1993). Cowan and Steel's Manual for the Identification of Medical Bacteria, 3rd edn. Cambridge: Cambridge University Press.

Chao, S.-H., Tomii, Y., Sasamoto, M., Fujimoto, J., Tsai, Y. C. \& Watanabe, K. (2008a). Lactobacillus capillatus sp. nov., a motile bacterium isolated from stinky tofu brine. Int J Syst Evol Microbiol 58, 2555-2559.

Chao, S.-H., Tomii, Y., Watanabe, K. \& Tsai, Y.-C. (2008b). Diversity of lactic acid bacteria in fermented brines used to make stinky tofu. Int J Food Microbiol 123, 134-141.

de Man, J. D., Rogosa, M. \& Sharpe, M. E. (1960). A medium for the cultivation of lactobacilli. J Appl Bacteriol 23, 130-135.

Dellaglio, F., Felis, G. E., Castioni, A., Torriani, S. \& Germond, J. E. (2005). Lactobacillus delbrueckii subsp. indicus subsp. nov., isolated from Indian dairy products. Int J Syst Evol Microbiol 55, 401-404. 
Endo, A., Mizuno, H. \& Okada, S. (2008). Monitoring the bacterial community during fermentation of sunki, an unsalted, fermented vegetable traditional to the Kiso area of Japan. Lett Appl Microbiol 47, 221-226.

Ezaki, T., Hashimoto, Y. \& Yabuuchi, E. (1989). Fluorometric deoxyribonucleic acid-deoxyribonucleic acid hybridization in microdilution wells as an alternative to membrane filter hybridization in which radioisotopes are used to determined genetic relatedness among bacterial strains. Int J Syst Bacteriol 39, 224-229.

Felsenstein, J. (1985). Confidence limits on phylogenies: an approach using the bootstrap. Evolution 39, 783-791.

Fitch, W. M. (1971). Toward defining the course of evolution: minimum change for a specific tree topology. Syst Zool 20, 406-416.

Gatti, M., Fornasari, M. E. \& Neviani, E. (2001). Differentiation of Lactobacillus delbrueckii subsp. bulgaricus and Lactobacillus delbrueckii subsp. lactis by SDS-PAGE of cell-wall proteins. Lett Appl Microbiol 32, 352-356.

Germond, J. E., Lapierre, L., Delley, M., Mollet, B., Felis, G. E. \& Dellaglio, F. (2003). Evolution of the bacterial species Lactobacillus delbrueckii: a partial genomic study with reflections on prokaryotic species concept. Mol Biol Evol 20, 93-104.

Giraffa, G., Lazzi, C., Gatti, M., Rossetti, L., Mora, D. \& Neviani, E. (2003). Molecular typing of Lactobacillus delbrueckii of dairy origin by PCR-RFLP of protein-coding genes. Int J Food Microbiol 82, 163-172.

Kandler, O. \& Weiss, N. (1986). The genus Lactobacillus, vol. 2. Baltimore: Williams \& Wilkins.

Kimura, M. (1980). A simple method for estimating evolutionary rates of base substitutions through comparative studies of nucleotide sequences. J Mol Evol 16, 111-120.

Kuykendall, L. D., Roy, M. A., O'Neill, J. J. \& Devine, T. E. (1988). Fatty acids, antibiotics resistance, and deoxyribonucleic acid homology groups of Bradyrhizobium japonicum. Int J Syst Bacteriol 38, 358-361.

Marmur, J. (1961). A procedure for the isolation of deoxyribonucleic acid from microorganisms. J Mol Biol 3, 208-218.

Mesbah, M., Premachandran, U. \& Whitman, W. B. (1989). Precise measurement of the $\mathrm{G}+\mathrm{C}$ content of deoxyribonucleic acid by highperformance liquid chromatography. Int J Syst Bacteriol 39, 159-167.

Michaylova, M., Minkova, S., Kimura, K., Sasaki, T. \& Isawa, K. (2007). Isolation and characterization of Lactobacillus delbrueckii ssp. bulgaricus and Streptococcus thermophilus from plants in Bulgaria. FEMS Microbiol Lett 269, 160-169.
Miller, L. T. (1982). Single derivatization method for routine analysis of bacterial whole-cell fatty acid methyl esters, including hydroxy acids. J Clin Microbiol 16, 584-586.

Pearson, W. R. \& Lipman, D. J. (1988). Improved tools for biological sequence comparison. Proc Natl Acad Sci U S A 85, 2444-2448.

Rzhetsky, A. \& Nei, M. (1992). A simple method for estimating and testing minimum-evolution trees. Mol Biol Evol 9, 945-967.

Saitou, N. \& Nei, M. (1987). The neighbor-joining method: a new method for reconstructing phylogenetic trees. Mol Biol Evol 4, 406-425.

Schleifer, K. H. \& Kandler, O. (1972). Peptidoglycan types of bacterial cell walls and their taxonomic implications. Bacteriol Rev 36, 407-477.

Sneath, P. H. A. \& Sokal, R. R. (1973). Numerical Taxonomy. San Francisco, CA: W. H. Freeman.

Tamura, K., Dudley, J., Nei, M. \& Kumar, S. (2007). MEGA4: molecular evolutionary genetics analysis (MEGA) software version 4.0. Mol Biol Evol 24, 1596-1599.

Tanigawa, K. \& Watanabe, K. (2011). Multilocus sequence typing reveals a novel subspeciation of Lactobacillus delbrueckii. Microbiology 157, 727-738.

Thompson, J. D., Gibson, T. J., Plewniak, F., Jeanmougin, F. \& Higgins, D. G. (1997). The CLUSTAL_X windows interface: flexible strategies for multiple sequence alignment aided by quality analysis tools. Nucleic Acids Res 25, 4876-4882.

Torriani, S., Zapparoli, G. \& Dellaglio, F. (1999). Use of PCR-based methods for rapid differentiation of Lactobacillus delbrueckii subsp. bulgaricus and L. delbrueckii subsp. lactis. Appl Environ Microbiol 65, 4351-4356.

Watanabe, K., Fujimoto, J., Sasamoto, M., Dugersuren, J., Tumursuh, T. \& Demberel, S. (2008). Diversity of lactic acid bacteria and yeasts in Airag and Tarag, traditional fermented milk products of Mongolia. World J Microbiol Biotechnol 24, 1313-1325.

Watanabe, K., Fujimoto, J., Tomii, Y., Sasamoto, M., Makino, H., Kudo, Y. \& Okada, S. (2009). Lactobacillus kisonensis sp. nov., Lactobacillus otakiensis sp. nov., Lactobacillus rapi sp. nov. and Lactobacillus sunkii sp. nov., heterofermentative species isolated from sunki, a Japanese traditional pickle. Int J Syst Evol Microbiol 59, 754-760.

Weiss, N., Schillinger, U. \& Kandler, O. (1983). Lactobacillus lactis, Lactobacillus leichmannii and Lactobacillus bulgaricus, subjective synonyms of Lactobacillus delbrueckii, and description of Lactobacillus delbrueckii subsp. lactis comb. nov. and Lactobacillus delbrueckii subsp. bulgaricus comb. nov. Syst Appl Microbiol 4, 552557. 